\title{
Policing bikers: confrontation or dialogue?
}

\author{
Paul Larsson ${ }^{1}$
}

Published online: 11 June 2018

(C) The Author(s) 2018

\begin{abstract}
This article deals with the policing of biker groups in Norway. It describes the two idealtypical approaches of dialogue and confrontation. It tries to explain why the police use certain methods. It finds that policing is rarely based on knowledge of what works or the causes of a problem. Instead the approaches chosen seem to reflect certain styles of policing described in cultural studies of the police.
\end{abstract}

Keywords Biker groups $\cdot$ Policing $\cdot$ Organised crime $\cdot$ Social control

There are two competing strategies policing bikers in Norway, so the story goes. One of confrontation and zero-tolerance, and a softer one based on dialogue. This article will describe these strategies and raise some questions: What can explain the use of these approaches and do they reflect more substantial differences in policing? Are there different styles of policing?

In this article the term outlaw motorcycle gangs (OMCG) will be used. To define outlaw motorcycle gangs (OMCGs) is not an easy task. But the literature points to certain elements that differentiate these clubs from common motorcycle clubs (Barker 2017, Lauchs et al. 2015). First of all they define themselves as outside the mainstream, they are the $1 \%$, the ones that deviate. The clubs first developed in the US after World War II, some formed by war veterans others mainly by local roughs. They share a certain style of dressing, values and a hierarchical organization. Lifestyle is centred on the bike, usually a Harley Davidson. Values are predominantly macho working class; freedom and brotherhood is central. They started as deviant groups of boys that appreciated fast bikes and drinking, and did not shy away from a fight. There is variation between clubs and how they have developed after they spread internationally. One central element of difference is whether the clubs kept going as mainly dominated by traditional barbarian culture (Lauchs et al. 2015) of drinking, fighting and minor

Paul Larsson

paul.larsson@phs.no

1 Norwegian Police University College, Oslo, Norway 
drug offences, or if they developed in the direction of organized crime with members committing major drug crimes, money laundering, extortion and dealing with prostitution. The two ideal types are often described as the conservatives (or traditionals) and the radicals. In clubs you can often find a mix of both conservatives, that mainly enjoy the 'barbarian lifestyle', and the radicals who use the clubs and 'the power of the patch' to commit serious crimes. Most research also seems to agree that the OMCGs are not criminal enterprises but gangs that are often exploited by members for committing crimes. Similarly, there appear to exist differences between countries when it comes to the development of the OMCGs. In the UK, OMCGs are mainly seen as traditionals, Germany more radical (Silverstone and Crane 2017), the Netherlands a mix of both (Blokland et al. 2017). Much also points towards differences between the Nordic countries with Danish clubs on the radical end while the Norwegian chapters seem to be more conservative (Klement 2016; Larsson 2016b).

When talking about the culture the term biker culture will be used. The development of the Norwegian biker culture and questions concerning criminal activity connected to the clubs will not be dealt with here, it has been described elsewhere (Larsson 2016a, 2016b; Skar 2016; Olsen 2015).

\section{Two camps}

A police officer from the Oslo Police Department, Eirik Jensen, has summed up the picture often presented of the police view of the bikers in Norway in an elegant, if not impartial way, as two basically different approaches.

... there are two camps in the police. Those who agree with Kripos $^{1}$ view of the bikers as national enemy number one, and those who rely more on facts not on simple images of boogeymen. In Oslo PD the threat from MC related crime is ranked number eight on the list of challenges in the capitol. The list has ten points. This indicates that we have a fair knowledge about what is going on in these clubs, we know that quite a few of them are criminals, but we also know that they are not among the top dogs in the drug market, and they produce less criminal cases in Oslo than other gangs. (Jensen 2015, p. 121)

This assessment might be true in Oslo, but is more problematic on a national scale. There are local variations in the police approach to the bikers, even if the pressure towards following the national strategy, that is close to what Jensen calls the Kripos perspective, has dominated since 2011 (Olsen 2015).

The two ideal types of approaches, often called the dialogue and confrontation models, are not uniquely Norwegian nor are they uniquely applicable to the biker field. Høyer (1999), in his book about the conflicts in the Nordic biker war, describes the same strategies used by the Danish police. The Copenhagen police is associated with an approach similar to the dialogue model, while the Hillerød

\footnotetext{
${ }^{1}$ The Norwegian NCIS.
} 
police and the national strategy have been more confrontational. Also the field of policing drugs, mainly at street-level, has seen similar approaches. At times zerotolerance and sweeping the streets seems to be in vogue, but dialogue is also well known (Mjåland 2016; Nafstad 2011).

\section{Dialogue}

Dialogue has always had a prominent and special position among the methods of policing. Historically the role of the police has been closely related to the ability to communicate with the population in town or shire ... Dialogue is not only the most used tool, but also the most prominent. The primary role of the police is to create safety. To secure safety there is a need to establish relations, understanding and respect to all individuals and groups. The Oslo PD has chosen an extensive dialogue with the whole of the population, independent of age, sex, sexual orientation, ethnicity, belief, political views, social status and criminal affiliation. Dialogue is a method used in most processes of negotiation and reconciliation in a wide array of policing in Oslo. (Politiet 2011, p. 4)

Dialogue has been in use in the policing of demonstrations, gangs, radicalized youth and other social problems since the 1980s. Swedish police has formalized it by developing a so-called dialogue-police used mainly to police demonstrations (Holgersson 2008). The method was developed in the aftermath of the riots in Gothenburg in 2001 when the police lost control over the demonstrations in connection with the European Council meeting. Casualties on the side of both police and the public were heavy.

The basics of this approach is to talk to people and develop face-to-face interaction between police officers and representatives of gangs, groups and organizations (Stubberud 2015). Some of these interactions are of a more permanent nature. These meetings are based on some degree of mutual trust and understanding between police and the others. At the same time the police is clear in that they do not tolerate crimes or harassment. The goal is to prevent crime and stop problems before they get worse.

In the case of OMCGs, dialogue has been effective when it comes to the exchange of information, not only from the bikers, but also the other way round from the police to the bikers. One of the most serious dangers have been feuds and rivalry between clubs. This has been most evident in Oslo where Bandidos and Hells Angels have their turfs within close proximity. The "normal" situation would have been that each group dominates one area, in Oslo they have to coexist within a limited space. The establishment of new groups or changes within the gangs within a close area can, as was seen in the period of conflict 1995-1998, create a disequilibrium and in a worst-case scenario can lead to a transcending spiral of conflict. Conflicts between OMCGs are quite common (Lauchs et al. 2015). They can go on for years, like the clashes between the Danish bikers that started in the 1970's and spread to a Nordic level with the clubs patching over to Hells Angels and Bandidos in the early 1990's (Klement 2016; Larsson 2016b). 
Even if they may go on for years the spark that sets of a feud (Bay 1998) can be an insignificant event, ${ }^{2}$ such as a classic bar brawl.

The officers in contact with the clubs must possess knowledge about the culture, understand bikes, and must be familiar with the environment, the persons involved and their history. This is essential in order to develop understanding, but also to gain respect and a common ground in the dialogue. The personal characteristics of both bikers and police officers are crucial in order to get a dialogue going. Eirik Jensen, the police officer cited above, is a case in point. He rides a Harley, has childhood friends who are bikers, and he shares much of the style, values and looks of bikers himself.

Critics have described the approach as starry-eyed and the police ending up "taking orders from criminals." It is depicted as a soft method, not popular among all officers. "Among the professionals that view conflict and repressive measures as the only solution, dialogue will be seen as naive, sending 'the wrong signals'. There are strong forces that openly advocate such world-views in the police." (Politiet 2011 p. 27).

The approach is not used in an isolated way. The clubs are often under surveillance by methods used in policing organized crime (von Lampe 2016). The dialogue rests on specific assumptions. It is not between equal partners. The police possess considerable force and the co-operation rests on terms the groups must abide by, for example if they are to get permission to arrange a meeting.

The dialogue consists of three levels. There is, first of all, a long term strategic dialogue. This entails, for example, dealing with potential conflicts when new clubs move in and the long term work preventing crime and recruitment to the clubs. In these instances the contacts are ongoing over time often followed up by dedicated personnel with established contacts in the clubs.

There is also a tactical dialogue that deals with events here and now. Emerging problems and challenges are dealt with on the spot, for example with respect to large biker meets, such as those the Hells Angels have arranged in Oslo. In such instances clear rules and terms are stated by the police. This might include that all members must be unarmed, treat police and public well and do not wear colours if they have a night on the town. These terms have so far been accepted by the clubs in Oslo and problems have been minimal.

Finally, there is an operative dialogue in everyday policing. This covers the ordinary contact between police on patrol and members of the clubs on a day-today basis. Officers are instructed to behave in a correct and well mannered fashion when dealing with club members and to not expose them to negative treatment. Contact with members is seen as a potentially important source of intelligence about what is going on in and between the clubs, about the activities of individual members, and so on.

\footnotetext{
${ }^{2}$ Miller (1958), Matza (1964) and other classic works on gangs describe these processes. The components of honour, to always back up a brother and natural rivalry between closed groups easily magnifies small events and may end in situations of ongoing feuds and fights.
} 


\section{Confrontation}

"You never talk to criminals (bikers), only in court. All other contact gives them status." (Kim Kliver, Danish Police inspector speaking to Norwegian official representatives, March 2011) ${ }^{3}$

Norwegian Police regularly develop action plans. Such plans are important because there are many different ways of policing. Police discretion provides plenty of room for a wide variety of approaches (Granér 2014). Action plans therefore point out, and sometimes prescribe, ways to deal with certain tasks. They also have a central role as policy documents stating two things, that something is actually done (symbolic action), and what it is that is believed to be the right measures.

The first national action plan on "Criminal MC-gangs" by the National Police directorate was issued for the period 2003-2008. In addition, the National Police Directorate has produced handbooks on a national level, the last from 2014 (Politidirektoratet 2014), and Kripos and others have devised local strategies and issued handbooks (Kripos 2009) that go more in detail about appropriate methods of policing. The most recent national action plan was for the period 2011 to 2015. Strategic goals were the same as in the earlier plan and included: "1) to reduce the number of criminal MC-gangs. 2) to prevent recruitment to the gangs, 3) to prevent the establishment of new biker groups." (Politidirektoratet 2012, p. 21).

To reach these goals the local police had to prioritize policing these clubs and to "take this threat seriously" (op. cit). As indicated, this was not an obvious thing to do since bikers were not seen as a problem in many districts.

Policing bikers is not left to the police alone, much is done on a municipal level by local authorities. These multi agency approaches are common also in Australia, Denmark and the Netherlands (Jahnsen 2017; Blokland et al. 2017; Lauchs et al. 2015). By drawing on the regulatory framework at the municipal level, fire and food regulations, alcohol licenses and so on can be utilized in a painstaking and creative way to make the everyday life of the clubs more cumbersome and prevent buildings and properties from being occupied by bikers. ${ }^{4}$ Real estate has been bought by municipalities for prices at times far above market value to deny clubs the opportunity to settle down. Police also put the clubs under stress by stopping and detaining visitors from other countries who wish to attend club events. Speed controls and technical checks on bikes and cars in the proximity of club houses and frequent controls of club facilities are likewise common. These kinds of measures are taken under the umbrella of preventive and proactive approaches.

The action plan stresses the following:

"However, measures that affect lifestyle, ideals and motivation for committing crimes is effective. For MC gangs the impact on the club and lifestyle will be highly undesirable. On the top of the list of effective measures are those that affect the gangs, such as the club, the chapter or when its members are held accountable in their role as members. Examples of such measures is confiscation

\footnotetext{
${ }^{3}$ Cited in Politiet 2011 p. 27.

${ }^{4}$ This is labelled administrative measures by von Lampe (2016).
} 
of the means of the "club" and liquor license or any order of moving, dismantling of fences, video cameras etc. Further down on the list of effective measures for the police, are the ones aimed at the members, such as confiscation of "colours" and driver's license, banishment from the club premises and such." (Politidirektoratet 2012, p. 22)

This might look like a gentle way of policing, but it can constitute infringements of individual rights. Raids on clubhouses and putting the clubs under stress by the use of heavily armed police are quite typical. In connection with parties and meets, massive police resources are mobilized to control and search arriving guests, at times stopping and returning them home (Larsson 2016a). Such approaches leave little room for reciprocity or understanding. The action plan states that dissemination of information to the municipalities and media is crucial: "The police is supposed to develop a strategic relation to media so the public gets what is considered good and correct information concerning biker-related crimes" (Politidirektoratet 2012, p. 22).

By focusing on biker-related crimes rather than the clubs as such, this means that only negative information is distributed to the exclusion of any opposing views (Olsen 2015). A clear example of one-sided information provide the seminars arranged by the police and the KS (central agency for the Municipalities) on bikers in 2011 and 2012. The aim of these seminars was to inform local politicians and professionals about the dangers posed by the $1 \%$ er clubs. There were no independent researchers among the speakers. ${ }^{5}$ Instead one of the most central contributors was the Swedish journalist Lasse Wierup who spoke on bikers based on his bestselling book "Swedish Mafia". The other speakers were experts from the Kripos and police investigators, like the Danish police officer cited above.

These seminars, held around the country, had the intended effect by arousing fear of things to come. A local daily paper reported the following: "KS last week hit the bulls eye with their Danish/Norwegian seminar on how to fight criminal MC gangs like the Hells Angels. Few of the approximately 100 Norwegian participants, or the nearly 20 journalists, went home untouched. No one left the conference without imagining and fearing similar developments in our country." (Hamar Arbeiderblad 1 April 2011, cit. in Olsen 2015, p. 119).

At first sight the action plan looks relatively open in its approaches towards the "biker problem". But the work of the Oslo PD or the use of dialogue is not mentioned at all. Reading the plan, no such approach exists. This is quite remarkable, given that many of the experts on bikers are in Oslo. In reality there was an escalation in the use of harsh and intervening methods. During 2011 and 2012 a number of raids were launched against clubhouses, not only of the Hells Angels and Bandidos but also those of supporter and hangaround clubs such as Devils Choice. In this context, the Hells Angels and their supporters were depicted as the most troublesome clubs (Kripos 2012, Larsson 2016b).

\section{The raids}

The raids carried out in 2011 and 2012 deserve special attention. Such raids are not mentioned as a strategy in the action plan and they represent something uncommon to

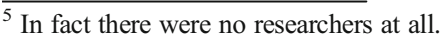


the Nordic way of policing. ${ }^{6}$ SWAT type raids on club houses, admittedly, had not been an entirely new thing, but the number of such actions grew considerably after 2011 . The official justifications for the raids were allegations of drug dealing and breach of rules concerning sale of alcohol, or to apprehend wanted persons. The raids were set off by the arrest of members for possession of drugs (often for personal use) and unregistered weapons, or in connection with cases of violence (often private altercations). Such raids are also well known from countries we Norwegians like to associate ourselves with, like Denmark (Klement 2016) and the Netherlands (Blokland et al. 2017).

At times the use of force by the police has been massive. One example: The club Four Horsemen had been on friendly terms with Hells Angels for years. They patched over to Devils Choice in 2014. Shortly thereafter the police raided their clubhouse. A number of armed police officers in typical SWAT gear in ten cars took part, a helicopter was used as well as drug sniffing dogs. Inside the club 14 individuals were present. Of these, two were detained and one was later charged with a minor drug offence (Glåmdalen 2014).

In the city of Bergen, the police raided the Hells Angels and supporter groups like Devils Choice. In one instance in February 2013, between 20 and 25 police officers raided the DC club house in response to a party. The result was a fine of 2500 kroner (£250) and the confiscation of 1100 bottles of beer, 801 of spirits and 131 of wine. In addition, two "civilian" women from Denmark who attended the party were put in detention by the police for the night and later sent home. Both media and the club questioned the methods used. Police responded that this was part of the national strategy against the $1 \%$ er groups:

"I see that this might look like shooting a sparrow with a canon when the case ends with a fine. But raids like the one in 2013 is a part of our strategy against the forms of crime that the $1 \%$ clubs generally represent." (cit. in Bergens tidende 30 December 2014)

Since 2011 there have been raids in Fredrikstad, Kristiansand, Kongsvinger, Jessheim, Hamar, Tromsø, Bodø, Bergen, Hundvågen and Trondheim. In these raids armed police, helicopters, dogs, armoured cars and in Bergen a cutting torch and a grinder were used to open a gate. Some of these raids ended with the confiscation of smaller amounts of drugs, usually amphetamines. The only case that sticks out with respect to serious results was the raid against the Hells Angels in Tromsø and Oslo. These operations ended with the conviction of eight men, many of them Hells Angels members or supporters, for trafficking and selling drugs. The confiscation of $20 \mathrm{k}$ of hash and $9.5 \mathrm{k}$ of meth in Tromsø is said to be the largest seizure in Northern-Norway. In an international perspective, however, these numbers do not look impressive. The main offender was the president of the Oslo Hells Angels who received a nine years prison sentence.

\footnotetext{
${ }^{6}$ The Nordic way is described as civilian in style, Norwegian police officers are unarmed, Peels ideals of a police of the people for the people are central.
} 
One might wonder why raids are used. In many instances they seem like an unnecessary display of force, since more subtle approaches might easily have reached the same goals. They might be a result of the focus on personal security. Police fear the clubs and want to protect themselves. But this is probably only half the story. The raids speak a clear language. The Police actually do something, they are highly visible and the sheer use of force seems to be a goal in itself. This might be said to be proactive policing, doing deterrence. But the element of performative policing, acting the role and taking control also seems plausible (Manning 2005).

\section{Effects?}

Confrontation easily results in negative treatment and stigmatization of parts of the MC community. The ultimate consequence of confrontation is the opposite of what the dialogue approach is preaching. The costs and negative effects are rarely mentioned. Documentation or research on the comparative outcomes of the dialogue and confrontational approaches are limited or non-existent. This also seems to be the case internationally (Lauchs et al. 2015; Bain and Lauchs 2017). Even if the action plans always stress the importance of evaluations none that is in anyway close to any scientific standards have so far been done in any Nordic country. These approaches are not chosen because of documented effects, or because they "work." In fact, policing is rarely knowledge-based.

Confrontation might scare some potential members, but the costs of doing so are obvious. The approach can make these groups even more closed, resulting in a higher level of antagonism, and raise the level of stress between the clubs. This, in turn, can easily spill over into conflicts and feuds. ${ }^{7}$ The consequences are also to be felt among MC clubs outside the OMCGs. Many motorcyclists with a club patch on their back feel the negative effects of the policing of the MC clubs. Ordinary clubs are often obliged not to accept any visitors from OMCGs at their events. This has resulted in negative reactions from clubs who consider themselves independent. It is not uncommon that "ordinary" motorcyclists feel stigmatized because of the negative public perception of OMCGs. The ethical considerations of a negative treatment of this kind have rarely been raised. The confrontational approach seems to collide head-on with central elements of policing that underline proportionality, flexibility and restraint in the use of force. There is an opening in the laws for use of force, in the formulation that methods shall be adequate, necessary and commensurate of the situation. ${ }^{8}$ Police

\footnotetext{
${ }^{7}$ It is often stated among biker clubs that the police try to make the clubs go to war against each other and to drop lies about rival clubs to spark conflicts (Høyer 1999). It is interesting that such lore exists among the clubs and it tells a lot about the lack of faith in the police.

${ }^{8}$ The Norwegian Police Act paragraph 6: "Endeavours shall be made to achieve the purpose of the police assignment through information, advice, order or warning or by taking regulatory or preventive action. The Police shall not employ stronger means unless weaker means are presumed to be inadequate or inappropriate, or unless such means have been attempted to no avail." In the ten principles both principle two that states that the police shall be civilian in style and number nine that emphasize the use of preventive measures is of importance. These principles are similar to Peels nine principles from 1829, especially the sixth: To use physical force only when the exercise of persuasion, advice and warning is found to be insufficient to obtain public cooperation to an extent necessary to secure observance of law or to restore order; and to use only the minimum degree of physical force which is necessary on any particular occasion for achieving a police objective.
} 
discretion is wide. But what does necessary or adequate mean? The confrontational approach is a reflection of a view in the police of OMCGs as dangerous and as serious criminals. ${ }^{9}$ The Hells Angels in particular are being presented as the most serious threat in organized crime. Decisive methods might then be seen as a necessity. This link between seriousness and police strategy will be questioned below.

\section{A problem to live with or the gravest threat in organized crime?}

As Eirik Jensen has pointed out, there has been and still is no agreement on how to best understand the OMCGs in Norway. The "Oslo view" has been to deal with them as any other threat or problem. Hells Angels and Bandidos are seen as a gang problem, not as a separate phenomenon. The active criminals in these clubs, are not perceived so much a problem of the clubs as of the criminal networks these individual members are a part of. The role of OMCGs in the drug business, at least in the Oslo region, is minor. They have a history of trafficking amphetamines, but their role in the hash market is rather marginal and there is an internal ban on heroin. In Denmark, Hells Angels used to be kingpins in the hash market (Møller 2010, Møller and Hesse 2013). This is not the case in Norway (Larsson 2009).

"When it comes to drugs, penal cases have shown that members of biker clubs as a rule commit their crimes without involving members of the clubs." (Politidirektoratet 2009)

Traditionally the OMCGs have been active in debt collection, although violence seems to be of less importance.

The other view can be illustrated by the magazine Norwegian Police (Norsk politi). They published a special issue on OMCGs in 2012. On the front page, decorated with a scull, we read: "The criminal one-percent clubs are among the networks representing the gravest threat in organized crime in Norway today." (Norsk Politi, nr. 2 2012).

The OMCGs are defined as 'trendsetters in organized crime', according to the magazine they define themselves as 'outside the Norwegian society', the members are described as criminals, as kingpins in serious crimes such as trafficking and trading in drugs and violence.

Maybe the difference between the two perspectives is small. Both use the phrase 'criminal MC-gangs' and focus on crime and anti-social behaviour. Representatives from the Oslo PD inform us that other parts of the country have different problems concerning the groups. The main goal in Oslo has not been to 'get rid of the clubs', but to reduce the level of conflict between them. There is an agreement between the police, Hells Angels and Bandidos that no other OMCG has the possibility to establish itself in Oslo. In many ways this seems like a parallel to the harm reduction perspective dealing with drugs. OMCGs are seen as one form of criminal gangs, not a phenomenon in

\footnotetext{
${ }^{9}$ As stated earlier Norwegian OMCGs are mainly conservative, not radicals (Larsson 2016b, Kripos 2012). Their role in connection to organized crime has been limited in Norway. This is not to say that some of the OMCGs are not seen as a problem of some dimension locally.
} 
itself. Similar approaches are used on OMCGs as other gangs (Politidirektoratet 2009). The confrontation approach is more concerned about the establishment of new clubs and supporters. The growth in the number of clubs and members and supporters in Norway since the turn of the century is evident (Politidirektoratet 2009). Similar developments seem to be the norm internationally (Bain and Lauchs 2017). In 2003 there were five Hells Angels chapters with a total of 60 members, four chapters of the Bandidos with also 60 members and two chapters of the Outlaws with an unknown number of members in Norway. Six years later, in 2009, there were seven Hells Angels chapters (90 members), six Bandidos chapters (40), six Outlaws chapter (70) and three chapters of the Coffin Cheaters (23). Today the numbers of 'identified' $1 \%$ members are approximately 250 .

\section{Styles of policing}

Why are different styles and strategies of policing chosen? For 'the man on the street' this might seem like a naive question. Approaches are chosen because they solve problems and work. There might also be other reasons, for example that the problem is so serious and dangerous or hidden that special methods are required. Police have to protect themselves so force is justifiable. Maybe 'weaker means are presumed to be inadequate or inappropriate' as the police act states.

\section{Are methods chosen because they work?}

We know little about the effects and outcome of the methods described above. The first question one must ask is, what is success and how do we measure good police work. The goal of the two actions plans (from 2003 and 2011) has been a reduction of OMCGs. The number of OMCGs and members have grown steadily in the period, including the formation of new $1 \%$ clubs. The situation is that Norway with 5 million inhabitants has a multitude of clubs like Hells Angels, Bandidos and Outlaws, but Coffin Cheaters, Devils Choice, Nomads, Gypsy Jokers, Gladiators, Mongols, Black Raven, Hog Riders, Gremium, Satudarah and Wino Crew have also been registered. As the Norwegian police have noted, there are no police districts that over time have been able to prevent any club from settling down (Politidirektoratet 2009). This in itself is no sign of failure, the number of clubs could have been higher and heavy handed police activity might have had some positive effects. But there are few, if any, signs that the growth has been less where the police have used confrontation.

Why the action plans have failed is uncertain. One thing is clear, however: the support for the 14 measures described in the action plan at the local level have been half-hearted, at best, in the period 2003-2008. The most important of these measures are (not to be mixed with police approaches): to develop a strategy to fight bikers, to develop a plan for the fight that is going to be implemented in the overall plan of the police district, that the Police directorate in cooperation with the general attorney is central in the co-ordinated efforts in cases that deal with MC crimes, most of the other measures are concerning co-operation internationally, locale and with other authorities.

Oslo PD on the other hand underlines the success of their own approach: "Since Oslo started with dialogue in 1998, there has not been any violent conflict between 
what is defined as the criminal MC-groups in Oslo. This is a result that police inspector Aas and his colleagues are proud of." (Norsk Politi 2-2012, p. 25).

The goals of the Oslo police, as stated above, differ from those of the action plan. Theirs are peace, order and control of the biker clubs. The courts, in two separate cases against Hells Angels, have given the Oslo PD credit for their approach. The Court view is that the dialogue approach in Oslo, where the MCgangs are established, have had the effect of reducing the risk for the use of guns, and conflicts between the clubs and society at large (Dagbladet 24/4-2014). In the absence of research that could determine the effect of the use of the dialogue in Oslo, there might be other reasons for the peaceful situation. One might claim that the problems in Oslo are different from the rest of Norway, so that there are good reasons for the use of a variety of strategies. One effect of the dialogue approach, however, is hard to disclaim: the Oslo PD by the use of this approach has been able to obtain the best intelligence, not only of what is going on among the bikers in Oslo, but also nationally and to a certain extent on a Nordic level.

This finding is in line with a central topic in studies of policing and police culture. The police organization is in a minor sense a learning organization and the 'natural' approach to policing is anti-academic, or intuitive-mechanic as Granér (2004) calls it. The ideal of knowledge-based policing has been central for the Norwegian police for more than a decade (Gundhus and Larsson 2014). The police are to learn from prior experience and strategies, operative actions, and investigation shall be rooted in analysis, research and best practice (what works). Studies of the reality of knowledge-based policing in Norway, in contrast, make for rather depressive reading (Andresen 2016). Policing is often guided by other stars, mainly old habits and notions of 'common-sense' and what is generally considered the right way to do things. These studies reflect the well documented sceptical stance towards academic knowledge, science and learning from books (Reiner 2000). Dialogue policing represents a more academic and reflective way of dealing with problems.

Granér (2014) develops a typology of policing where the practical-intellectual approach and the mechanical-intuitive represent two extremes. They might sum up some of the central aspects of dialogue and confrontation. "The practicalintellectual approach is identified by a way of thinking that has logic reasoning and proven facts as basis. ... Professional ideals are defended in the work done independent of personal preferences, with a clear ethics of work and an openness to examine own beliefs. ... [this stance] is associated with a way of thinking that underlines human rights and equality, and distances itself from racism and have a negative view on the use of violence." (Granér 2014, p. 146) This seems to sum up central elements of the dialogue. On the other side there is the mechanicalintuitive. "To act and make decisions fast is central for the mechanical-intuitive approach. This action-approach is reflected in the types of knowledge demanded. The knowledge shall be concrete, easily accessible, definitive and give direct action guidance. ... There is a preference to view both oneself and the surroundings based on beliefs that can be summarized in plain categories. ... Work is based on traditionally rooted approaches based on force and authority. ... Common sense is often referred to." (Granér 2014, p. 146) Much of this seems familiar with the confrontation approach. There are other authors touching on similar aspects that will be dealt with below. 


\section{Are methods chosen to counter serious threats?}

For many police officers a zero-tolerance approach seems appropriate because they view the OMCGs as among the most serious threats. Massive force might be a way to protect the officers from the threat of violence.

Rank and file police officers often share a belief in the deterrent effect of zerotolerance policing and the use of force. This is reflected in the action plans, but manifests itself more clearly in the practical day-to-day police work and in the raids on club compounds. The idea is simple: make life unpleasant and make membership unattractive, then members will choose to leave the clubs. This approach has a strong moral basis, but is to a smaller degree rooted in knowledge about the dynamics of gangs and secret societies. In fact, it may have effects opposite to what is intended. This is pointed out by Blokland et al. (2017) in their study of policing OMCGs in the Netherlands. They underline the differences between the OMCGs and their criminal involvement and that this should be taken into account by the police when choosing how to deal with the clubs. When parts of the OMCG community that are less criminally active feel harassed and discriminated against this may only strengthen their mutual bonds and allegiance to their club and may alienate them further from society. Zero-tolerance also seems to be oblivious of stigma theory and the idea that public reactions and branding might contribute to amplifying problems instead of solving them.

Few, if any, in the police will say that clubs like the Hells Angels or Bandidos are groups of law-abiding nice-guys. But there are differences when it comes to the idea of how big a threat they actually pose locally and on a national scale. The two main types of crimes associated with members of the groups in Norway are drug related offences and debt collection, although much of the debt collection is legal or occurs in a legal grey zone. Norway is a low crime country, so that the establishment of an OMCG might easily be seen as a crime invasion. In some places, bikers are indeed regarded as a big problem; in other places the clubs are welcomed because they bring life and action. This could be seen in a still ongoing case where Gremium MC wanted to acquire an old assembly hall locally in my region. The police and the municipality warned against it, neighbours welcomed the club. ${ }^{10}$

\section{Geography and morals}

Steve Herbert in his classic "Policing Space" (1997) points to the central element of controlling space to understand police work. The control of social boundaries and space is a central element. Biker clubs threaten this by working along the same logic themselves. ${ }^{11}$ The idea of a "quasi police" controlling an area itself must feel like wrong for many police officers.

"The bikers are symbols of evil and the enemy. They have become a 'suitable enemy' for the police. It is like a religion, there are no other groups that arouse such

\footnotetext{
${ }^{10}$ This case is still ongoing. The municipal authorities wanted them out of the old assembly, Gremium answered by registering as a religious group worshipping the number of 7 .

${ }^{11}$ This is much what Klaus von Lampe (2016) describes as extra-legal governance a central element in some forms of organized crime.
} 
strong feelings among the police as the bikers." (Jensen 2015, p. 122). They represent the 'other side'. Shutting people out, rejecting club houses and closing down or confiscating clubs are a part of what Herbert describes as controlling the geography of morals. For the police these are symbols of the enemy, the unclean that should be sanitized from the city. Not only this, it is also a symbol threatening the police monopoly of power. It has been pointed out that OMCGs share many of the cultural values as many police subcultures, toughness, risk taking and the preference for fast cars and bikes (Silverstone and Crane 2017). This also makes the OMCG "the black brother" and a thorn in the side.

\section{Styles of policing and police culture}

A central finding in police studies is that there are fundamentally different approaches to policing, or styles of policing. Muir (1977) in his study of the "Streetcorner politician" starts by asking: "What makes a police officer good"? He identified different styles of policing labelled the professional, the enforcer, the avoider and the reciprocator. For Muir a good cop - or professional - is one who understands people in trouble but at the same time use their force to try to help and solve problems. The enforcer, in contrast, uses force when it is needed but does not understand the need to restrain it. The avoider has a cynical perception of the public and avoids the use of force, or to step in at all. The reciprocator understands the situation and the morality, but does not use force, even when needed. To these two types we could add the tired cop or uniform carrier, who avoids action and seeks places where there is not much happening, and the legalist - the one who mainly goes by the book, not using too much creativity or discretion (Granér 2004). These styles depend on the cop developing two virtues, grasping the "nature of human suffering" and resolving the contradiction of "achieving just ends with coercive means" (Muir 1977, p. 3-4).

One central element in the development of different styles pointed out by both Muir and in later studies (Reiner 2000 and Granér 2004) is how the police respond to the public and to police "property." Police often meet people in a vulnerable situation, with problems, often drunk or behaving in ways seen as wrong, immoral or irrational. Police develop strategies of making sense of and tackling these situations (Bittner 1967). Police may become cynical, or develop a clear distance between themselves and "the others," label different groups as deviants or troublesome or get to understand them.

Returning to policing OMCGs we mainly got two groups, the professional and the enforcer. Behind the dialogue lies an assumption that the bikers can be treated as more or less sensitive individuals. They sign agreements and can to a certain extent be trusted. This means that they are seen as responsible actors. On the other hand there is a strong tendency to describe them primarily as criminals. By being serious criminals they are different from us, not to be trusted or in a position to enter into agreements with the police. If you top this with the expectation that they are dangerous, a cynical view is easily the result. They actually deserve to be met by force, 'the only thing they understand.' It should be pointed out that the enforcers probably would view the professionals as reciprocators, 'soft guys', too understanding and not willing or able to use force when needed.

There are variations in police culture within police organizations. It is documented that especially secret or covert forces, often with easy access to the use of power and 
coercive methods, might develop ways of policing that deviate from what is institutionally accepted (Fijnaut and Marx 1995). Some are associated with excessive use of force, often on segments of the population that for some reason are seen as troublesome: living in 'the wrong' part of town, drug users, political radicals, street-gangs, deviant youth groups, and so on (Fassin 2013). OMCGs are on that list.

There is an import of styles of policing and 'tough' approaches seem to be favoured. As early as the late 1980s, police officers from Trondheim went to the US to learn about policing OMCGs (Larsson 2016b). They returned with the message that bikers were hardened criminals and should be treated as such. Things would only grow to become worse. This was also one of the first times the phrase organized crime was used in the Norwegian context. OMCGs have since come to epitomize organized crime in Norway (Larsson 2016a). It is important to note in this respect that many of the officers taking on bikers in Norway used to have a background in drug enforcement where covert methods were first applied. For these officers the OMCGs were of interest primarily because of their links to drugs. The connections between OMCG and drugs are well documented (Bain and Lauchs 2017, Klement 2016). Investigation of drug cases often serve as 'door openers' for measures against OMCGs, including the use of informants and electronic surveillance (Larsson 2015). At the same time, it is not illegal to be a member of such clubs in Norway and the courts have come to the conclusion, most recently in 2015, that Hells Angels are not organized crime ${ }^{12}$ according to the Norwegian penal law (Larsson 2016a).

The international dimension in the policing of bikers is not to be underestimated. Norwegian police, with Kripos as the central division, have been and continue to be involved in international co-operation with respect to bikers on both a Nordic (E6), European (Rocker, Monitor) and international level. This co-operation not only entails intelligence sharing; the diffusion of concepts and ways of policing is also a central part of the exchange. Interestingly many of the same stories are repeated as examples of the violence and the threat posed by bikers, even if some of the stories, as dreadful as they may be, are 30-40 years old and from totally different cultures and continents. The confrontational approach has been most affected by international influences. Apart from the US, Danish police seem to have had the greatest impact.

\section{Closing remarks}

In recent years there has been little attention paid to the biker problem. Attention has gone elsewhere, mainly to the problems connected to mass immigration (Kripos 2015). This seems to be symptomatic for modern crime policy: problems are not solved, instead we grow tired of them and move on to new ones that pop up (Pratt 2007).

The number of OMCG clubs has grown steadily in recent years, and so has the average age of their members (Lauchs et al. 2015). Input of new blood is limited (Skar 2016). There has been a flux of new groups such as Gremium, Coffin Cheaters, Devils Choice, Gypsy Jokers, Mongols, Black Raven, Hog Riders, Satudarah and Wino Crew. Old Norwegian OMCGs like Gladiators have been re-started. Members in these "new" clubs are often guys in their 40s. Many of these recruits are said to have limited

\footnotetext{
${ }^{12}$ See also Lauchs et al. (2015).
} 
criminal background. It seems that the lifestyle and identity is the main attraction. On the other hand this life seems to have a limited appeal to youngsters. Police claim that new recruitment to supporting clubs is made from street criminals and boys with no prior connection to the biker world and values. This was already stated in 2003 (Politidirektoratet 2003) and has regionally been seen as a major problem. Internationally this blurring of lines between street gangs and other forms of youth gangs and OMCGs has been observed in many countries (von Lampe 2016), like Australia (Lauchs 2017), Sweden and Denmark (Klement et al. 2010, Jacobsen 2012).

The level of aggression between the clubs nationally has been low and there has been peace in Oslo since the turn of the century. This is explained in different ways by the police and the biker groups themselves. It is claimed that the fact that Hells Angels are in a dominating position is a reason for the stability. Peacefulness can be seen as 'good for business.' For many of the 'oldtimers' the prospect of returning to war and stress is highly undesirable. What effect the police strategies have had for the current situation is open for interpretations.

There is no doubt that OMCGs in Norway also in the future will cause problems and be on the list of police priorities. Using police resources on intelligence, supervision and analysis of the most active clubs and members is sensible, to do otherwise might be very risky. But it is important not to treat all OMCGs the same way, and not to use unnecessary or abusive methods (Blokland et al. 2017). I fully agree with the statement by Lauchs et al. (2015) summing up their book on OMCG: "Policing of these groups is necessary but the political and law enforcement responses should recognize the nuances of the OMCG environment and provide a proportionate response to ensure that criminals within the groups are investigated and tried through a fair procedure, and punished to the level that fits the crimes of which they are convicted." (op cit. p. 94) I guess that quite a few members of the OMCGs also would agree with this statement. It is not a question if the police should react, but what they should do and how they should do it.

The response to the growth in OMCGs in Norway has been lacking these nuances. The conflict approach has been built upon the idea that when clubs patch over to Hells Angels, Bandidos, Outlaws and so on in Norway they will more or less automatically become much more criminal than they used to be when they were the Shabby Ones or Rowdies because of their strengthened deviant networks. The conflict approach also rested on the import of ways of policing that was viewed as fitting. If and how these ways of policing worked was usually backed by personal experiences and selected stories, not by evaluations and research. The outcome of the dialogue approach has not been researched either. At least this way of policing is not as troublesome when it comes to use of force and stigmatization and more in line with traditional values of policing. Raids and zero-tolerance approaches often feel like an extra penalty, directed towards all members criminal or not.

The two approaches reflect different styles of policing. "What to do" about the bikers varies and reflects "traditionally rooted approaches" used in other fields of policing. Styles of policing is also linked to committed police officers and traditional ways of solving problems. There are, as Muir (1977) points out, both variations in police culture and in individual styles of policing. One can say that the dialog approach suits the professional with his ability to understand people and use appropriate force, while the enforcer that does not hold back when it comes to the use of power but easily 
might overdo it will feel more at home with a confronting style. The importance of international cooperation is obvious. The confronting style has been influenced by developments and strategies in the US and in Denmark. Modes of policing reflect on a much wider context. There is always a political element when it comes to what measures are viewed as appropriate in dealing with social problems. This brings us to the political responses not only to OMCGs, but also to how to respond to such different issues as drugs, immigration, terror and organized crime. The preference of tough ways of dealing with such problems is closely linked to the developments in criminal politics and the perceived necessity to act, show force and give an impression of control and efficiency. If this is the best for society, that is another question.

\section{Compliance with ethical standards}

Conflict of interest There are no conflicts of interest.

Human Studies This article does not contain any studies with human participants performed by the author.

Open Access This article is distributed under the terms of the Creative Commons Attribution 4.0 International License (http://creativecommons.org/licenses/by/4.0/), which permits unrestricted use, distribution, and reproduction in any medium, provided you give appropriate credit to the original author(s) and the source, provide a link to the Creative Commons license, and indicate if changes were made.

\section{References}

Andresen, A.H. (2016). I hvilken grad kan masteroppgavene på PHS synliggiøre betydningen av høyere utdanning for å utvikle politiet som en kunnskapsstyrt og laerende organisasjon?, Unpublished paper

Bain A, Lauchs M (2017) Understanding the Outlaw Motorcycle Gangs: International Perspectives. Carolina Academic Press, Durham

Barker T (2017) Motorcycle Clubs or Criminal Gangs on Wheels. In: Bain A, Lauchs M (eds) Understanding the Outlaw Motorcycle Gangs: International Perspectives. Carolina Academic Press, Durham, pp 7-25

Bay J (1998) Konfliktar mellan mc-klubbar. In: Sernhede O (ed) Olja, Krom och manlig gemenskap. En antologi om bikerkulturen. Daidalos förlag, Göteborg

Bittner E (1967) The Police on skid row: a study in peackeeping. Am Sociol Rev 32(5):699-715

Blokland A, Soudijn M, van der Leest W (2017) Outlaw Bikers in the Netherlands: Clubs, Social Criminal Organizations or Gangs? In: Bain A, Lauchs M (eds) Understanding the Outlaw Motorcycle Gangs: International Perspectives. Carolina Academic Press, Durham, pp 91-111

Dagbladet 24 April 2014 "Retten roser 'Jensen-modellen', refser Kripos - Kripos stigmatiserer Hells Angels" Fassin D (2013) Enforcing Order. An Ethnography of Urban Policing. Polity Press, Cambridge

Fijnaut C, Marx G (1995) Undercover. Police surveillance in comparative perspective. Hague, Kluwer Law International

Glåmdalen 19 March 2014 "To personer siktet etter MC-razzia"

Granér R (2004) Pattrulerande poliseres yrkeskultur. Lund Dissertations, Socialhögskolan, Lund

Granér R (2014) Selvstendige sheriffer eller lojale byråkrater - om patruljerende politis yrkeskultur. In: Larsson P, Gundhus H, Granér R (eds) Innføring i politivitenskap. Cappelen Damm, Oslo, pp 134-153

Gundhus HO, Larsson P (2014) Fremtidens politi? In: Larsson P, Gundhus H, Granér R (eds) Innføring i politivitenskap. Cappelen Damm, Oslo, pp 273-301

Herbert S (1997) Policing Space. Territoriality and the Los Angeles Police Department. University of Minnesota Press, Minnesota

Holgersson S (2008) Dialogpolis. Erfarenheter, iakttagelser och möjligheter. Växjö University Studies in Policing nr. 2, Växjö

Høyer T (1999) Den store nordiske rockerkrig. Gyldendal, København 
Jacobsen MH (2012) Skyggelandet. In: Ungdomskultur, kriminalitetskultur og bandekultur i dansk belysning. Syddansk Universitetsforlag, Odense

Jahnsen S (2017) Banning and banishing outlaw motorcycle gangs. In: Fyfe N, Gundhus H, Rønn K (eds) Moral issues in intelligence-led policing. Routledge, London, pp 283-302

Jensen E (2015) På innsiden. Historien om mitt politiliv. Kagge forlag, Oslo

Klement C (2016) Three Papers on Crime among Outlaw Bikers in Denmark, Ph.D. Dissertation, Copenhagen: The Faculty of Law, University of Copenhagen

Klement C, Kyvsgaard B, Pedersen A-JB (2010) Rockere, bander og risikofaktorer. Justisministeriets forskningskontor, København

Kripos (2009) Patruljehåndok 1\% kriminelle MC-gjenger, Politiet, hefte (Report exempt from the public)

Kripos (2012) Hells Angels Norway og kriminalitet, Rapport (Report exempt from the public)

Kripos (2015) Trendrapport. Den organiserte kriminaliteten, Rapport, Oslo

Larsson P (2009) Up in smoke! Hash smuggling the Norwegian way. In: Ingvaldsen K, Sørli Lundgren V (eds) Organised crime. Norms, markets, regulation and research. Unipub, Oslo, pp 63-82

Larsson P (2015) Politistrategier mot narkotika. In: Drugs: what is the problem and how do we perceive it? Policies on drugs in the Nordic Countries, pp. 78-89. NSfK Working Group Report

Larsson P (2016a) "The Big Scare": Bikers and the Construction of Organized Crime in Norway. In: Antonopoulos G (ed) Illegal Entrepreneurship, Organized Crime and Social Control. Essays in Honor of Dick Hobbs. Springer, Cham, pp 205-218

Larsson P (2016b) Scary Monsters. The bikers: a moral panic? In: van Duyne PC, Scheinost M, Antonopoulos G, Harvey J, von Lampe K (eds) Narratives on Organised Crime in Europe, Criminals, Corrupters \& Policy. Wolf Legal Publishers, Oisterwijk, pp 405-426

Lauchs M (2017) Nike Bikies. In: Bain A, Lauchs M (eds) Understanding the Outlaw Motorcycle Gangs: International Perspectives. Carolina Academic Press, Durham, pp 115-134

Lauchs M, Andy B, Bell P (2015) Outlaw Motorcycle Gangs. A Theoretical Perspective. Palgrave Macmillan, Houndmills

Manning PK (2005) The police: mandate, strategies and appearances. In: Newburn T (ed) Policing. Key Readings. Collumpton, Willan Publishing, pp 191-214

Matza D (1964) Delinquency and Drift. John Wiley and Sons, New York

Miller WB (1958) Lower Class Culture as a generating milieu of gang delinquency. J Soc Issues 14:5-19

Mjåland K (2016) Neglect, reject, accept: Harm reduction perspectives on law enforcement in open drug scenes, paper presented at the annual meeting of the European Society of Criminology, Münster

Møller K (2010) Policy Displacement and Disparate Sanctioning from Policing Cannabis in Denmark. J Scand Stud Criminol Crime Prev 11(2):135-150

Møller K, Hesse M (2013) Drug market disruption and systemic violence: Cannabis markets in Copenhagen. Eur J Criminol 10(2):206-221

Muir KW Jr (1977) Police. Streetcorner Politicians. The University of Chicago Press, Chicago

Nafstad I (2011) Rusbrukere i det offentlige rom i Oslo: De kriminelle kroppene. Materialisten: Tidsskrift for forskning, fagkritikk og teoretisk debatt 38(1):26-48

Norsk politi nr. 22012 Oslo: Politidirektoratet

Olsen A (2015) Engler og demonisering. Politiretorikkens gjennomslagskraft. Master thesis in Journalism at the Institutt for medier og kommunikasjon, Oslo: University of Oslo. https://www.duo.uio. no/handle/10852/49770

Politidirektoratet (2003) National threat assessement. Politidirektoratet, Oslo.

Politidirektoratet (2009) Evaluering av handlingsplanen. Politiets bekjempelse av kriminelle MC-miljøer 2003-2008. (not in print)

Politidirektoratet (2012) Politiets bekjempelse av kriminelle MC-gjenger i perioden 2011-2015, Oslo. https://www.politi.no/vedlegg/rapport/Vedlegg_1706.pdf

Politidirektoratet (2014) Forebygge og bekjempe kriminalitet fra énprosentmiljøet og kriminelle MC-gjenger. Håndbok for politi og kommunale myndigheter. Oslo. https://www.politi.no/vedlegg/lokale_ vedlegg/politidirektoratet/Vedlegg_2456.pdf

Politiet (2011) Alt starter og avsluttes med et håndtrykk. Dialog med gjengstrukturer, erfaringer, resultat og råd. Report, Oslo: Oslo Politidistrikt

Pratt J (2007) Penal populism. Routledge, London

Reiner R (2000) The Politics of the Police. Oxford University Press, Oxford

Silverstone D, Crane P (2017) Mapping and Conceptualizing Organized Motorcycle Gangs: The British, German and Spanish Experience. In: Bain A, Lauchs M (eds) Understanding the Outlaw Motorcycle Gangs: International Perspectives. Carolina Academic Press, Durham, pp 67-86 
Skar IK (2016) Biker forever, forever biker - en etnografisk studie av den norske bikerkulturen. Master thesis in Sociology at the University of Oslo. https:/www.duo.uio.no/bitstream/handle/10852/52816/Skar. pdf? sequence $=1$

Stubberud R (2015) Dialog som kriminalitetsforebyggende metode overfor kriminelle nettverk og gjenger. In: Korsell L, Larsson P, Christophersen JG (eds) Ekstraordniære tider. Festskrift til Per Ole Johansens 70 års dag. Nouvs forlag, Oslo, pp 249-258

von Lampe K (2016) Organized Crime. Analyzing Illegal Activities, Criminal Structures, and Extra-legal Governance. Sage, Thousand Oaks 